\title{
LEGAL AND MORAL APPROACH OVER PRESS OFFENCES IN WESTERN DEMOCRACIES IN ROMANIA
}

\author{
C. A. Păiuşescu
}

\section{Cristina-Anca Păiușescu}

Faculty of Political Sciences

"Dimitrie Cantemir" Christian University, Bucharest, Romania

*Correspondence: Cristina Anca Păiuşescu, "Dimitrie Cantemir" Christian University, 176

Splaiul Unirii St., 4 District, Bucharest, Romania

E-mail: ancamili@yahoo.com

\begin{abstract}
The essence of a democracy consists of the political rights of its citizens of their ability to influence political decision, to challenge and to participate directly in the management of the state. How it could all this happen without a free press to express the level of externalization of thoughts and ideas of freedom of expression of public opinion. The press is one of the forms of expression of public opinion and in terms of its functions, the average is of major importance for society as a whole and for the individuals who compose it. However, it is imperative to create moral and legal rules that guide the work of journalists, to avoid press offenses. They are created both by the state and journalists, themselves, by selfreglementation.
\end{abstract}

Keywords: press-freedom, press-democracy, legal limits, selfreglementation

\section{Introduction}

World Democracies faces a number of various challenges, both inside and outside problems which have to cope with, starting on the level of political representation, the problem of technocracy, the matter of oligarchy within powerful parties, to the institutional problems. A new challenge for western democracies is the pressure coming from the increasing demands for recognition of various types of human rights and the increasing requirement of legalization of relationships that once belonged to the sphere of "immorality".

1. The relationship between law, morality and ethics in the media

For the media, the triad law - morality - ethics has an unique connotation and its casting is presenting as an intractable paradox ${ }^{1}$. Although the media is governing our lives and they are indispensable public service, the journalists hardly accept, or reject the idea legal constraint in their profession, some journalists even ignoring the rules of morality or ethics.

Because the term "ethics" often irritates media professionals and because a minimum consensus of professional conduct is required, there is a new concept created for them quality control - a concept that covers both ethics, morality, professional ethics within the existing legal frame of the media ${ }^{2}$. A practitioner is virtuous as an ideal professional purposes and may become a successful practitioner, but this often means to win badly. He focuses on excellence and the customer and too little on money and his image.

\footnotetext{
${ }^{1}$ D. T. Popa, Dreptul comunicării, Norma Publishing House, Bucharest, 1999, p. 49.

${ }^{2}$ Idem.
} 
"Professional ethics" relates to compliance of the supreme ideal or value pursued by practicing a certain profession, a value that can not be the "enrichment" unconditional, but rather it is an immaterial amount and honorable man who is dedicated to the profession ${ }^{3}$.

The juridical norms draw their consistency from social norms, especially from the religious norms; it is the religious norms that imposed respect of man toward man and respect for the rights and liberties of each and every individual. The state of law - as a political institution - is forced to assure the observance of each individual's rights and to contribute to their entering into practice; more precisely, the state has to create simple and efficient mechanisms directed toward a concrete achievement of the fundamental rights ${ }^{4}$.

When we talk about the relationship between law, ethics/morality and ethics in the professional media we must consider all possible nuances that can result from this juxtaposition of concepts. Options offered by the justice system, for instance the concepts of "innocence" or "guilt", are simply inappropriate for issues involving news production. Courts are instruments with lack from words shades. They often require evidence that may be appropriate in a legal process, but that stifles political speech. Some judges expect journalists to prove everything they write, just like a lawyer with forensic and concrete evidences, and witnesses. They forget that journalists do not have the power to arrest a person and that people shamelessly lie to reporters. Journalists write as much as they can about a topic in the time they have available. They know from experience that the great revelation they have today could be contradicted by what they could find tomorrow.

2. Freedom of expression in the media and press offenses

Freedom of expression can be achieved by speech, writing, images or sounds. Freedom of expression is general and it involves the "freedom of the press", but cannot to be confused with it. Expression of the press has certain features in the object or the holders. Freedom of expression needs no limitations or restrictions as there is a need for news media in general. Press freedom is subordinated to the right to information. It is the nature of freedom of expression in the media unlike other forms of freedom of expression (eg, artistic). Due to the nature of freedom of expression, many constitutions of democratic countries regulates distinct media freedom of expression from freedom of speech. We may even say that the press does not enjoy the same fullness of freedom of expression as other forms of expression of thoughts or feelings (e.g. artistic manifestations) it does not have the same constitutional immunity. In every State there must be maintained the law established by the Constitution and the press ${ }^{5}$ shall enjoy immunity only if disclosures are consistent with the constitutional order ${ }^{6}$.

The Romanian Constitution prohibites defame of the country and the nation, any instigation to a war of aggression, national, racial, class or religious hatred, incitement to discrimination, territorial separatism or public violence and obscene conduct contrary to morality. Media must obey these limits of expression and any item that could defame Romanian nation or that would incite to discrimination, or to overthrow the constitutional values enshrined, could be considered that reverses the order desired by constituent and is therefore punishable and is being considered "news offenses".

3 . The need of imposing legal rules on freedom of press

The freedom of the press is essential for democracy and pluralistic culture. A free press requires a variety of publication that derives a variety of information and views from. Of these, people gather what they themselves useful to process information according to their own convictions. Thus people can knowingly participate in social life, to defend democratic

\footnotetext{
${ }^{3}$ M. Luburici, Teoria generală a dreptului, Oscar Print Publishing House, Bucharest, 2010, p. 26.

${ }^{4}$ Nicoleta Elena Buzatu, Cristina Anca Păiuşescu, "Man's Rights" or The "Harmonious Communion Between Lay and Religion in the Universal Order”, Agora International of Juridical Sciences no 2/2011, Agora University Press, Oradea, p. 290.

${ }^{5} \mathrm{~V}$. Ionescu, Unele controverse în dreptul penal la sfârşit de mileniu in "Dreptul” Review, no 7/1999, p.70.

${ }^{6}$ Idem.
} 
values. For information reaching the public to be real and honest, the press must be free. The role of media is to play as real and accurate information on the one hand, but the media's role is also to problematize and discuss and debate political decisions, on the other hand. A democratic political system is characterized by the ability to engage people in politics, the right of everyone to vote and to be elected to state and everyone's right to question political decisions. And press freedom had provided an essential condition so that the exercise of these functions had positive effects.

The term "legal" or "legislative" or refer to any action initiated by a parliament on media activity ${ }^{7}$. Legislation on defamation and/or insulting, which is found in many countries fall into this category; also in this category are the laws against incitement to racial hatred and restrictions on the right of journalists to name victims of rape or sexual abuse, which are found in many countries. Freedom of information legislation requires authorities to provide all information, including journalists, on request. In many countries still exists rigid laws covering state secrecy, but, progressive, the advocates of freedom of information successfully change these restrictions. In some European countries with a tradition of experimentation democracy such as France, Britain and others, the duty of journalists to protect confidential sources required by law. Thus, legislative regulation is already part of the work of journalists ${ }^{8}$. In some cases, they appreciate it ${ }^{9}$.

\section{Self-regulation or Code of Ethics for journalists}

There is an ethical issue in almost everything he does a journalist. Objectivity and accuracy must be the journalist gold, whether they report or take account of a common event, a fashion event or serious political problems. Because of the pressures that bear during their work, journalists must constantly review their professional values. To ensure this, some media companies invest serious training or setting up their own schools of journalism or working with academic institutions specializing in journalism.

The first and most important step towards self-regulation in the media is the commitment of the journalist to an ethical code ${ }^{10}$. The journalists can create their own code of ethics but isolated working environment. Difficult to ask questions without fear of retaliation, a reporter must have solidarity behind colleagues, which is generated by membership of a trade union. In addition of solidarity, a trade union of journalists can provide a platform for discussion on ethical issues ${ }^{11}$. For example, in the UK, the National Union of Journalists has an Ethics Council whose function is to promote the Code of Ethics of the Syndicate by issuing guidance notes to its members and by analyzing complaints concerning violations of the Code $^{12}$.

In practice, every media company has adopted a certain style of reporting and editing the news. The main reason is that the reader, listener or viewer may be confused when a newspaper changes his approach to certain issues. This style can affect the quality of the paper or station appears. In most Western media organizations, work style is on paper as a "manual" that becomes tool for each team member. These manuals can provide guidance on ethical issues for journalists, while the institution of media self-regulation involves the creation of a mechanism to respond to public complaints of any violation of accepted standards. One example is the appointment of a representative of readers at some national newspapers - usually heads of departments, experienced people - whose role is to receive complaints and to link the plaintiffs and newspaper. The purpose of this institution is to enable reader's greater access to newspaper and provide as impartial judge. Few newspapers -

\footnotetext{
${ }^{7}$ Cristina Anca Păiuşescu, Oana Duță, Dreptul comunicării. Considerații teoretice şi legislație relevantă, "Editura Universitară" Publishing House, Bucharest, 2011, p. 19.

${ }^{8}$ Idem.

${ }^{9}$ Idem.

${ }^{10}$ C. F. Popescu, Etica jurnalistică şi legislația presei, A.N.I. Publishing House, Bucharest, 2006, p. 11.

${ }^{11}$ Idem.

${ }^{12}$ National Union of Journalists Ethic

http://www.nuj.org.uk/inner.php?docid=59\&PHPSESSID=41fe42e05 e0c3abd4c7432db5c23f61d.
} 
usually among serious - have such an initiative. For example, the UK newspaper The Guardian is one of three national newspapers called a representative of readers, whose mission is to respond directly to complaints, to write erratum lists and clarifications that are published daily and writes a weekly column to deal with ethical issues ${ }^{13}$.

\section{Ethical Councils}

When speaking of self-regulation, generally peoples refers to national "ethics board", "the complaints Committee" or to "ombudsman" who must monitor each newspaper to observe a set of Universally accepted values. These "Ethical Council" may be entirely financed by industry media journalists only or both groups, and sometimes receive government assistance. A Board of Ethics will publish a code of conduct approved by media organizations and journalists. It is crucial that newspapers across the country join this code. Sometimes it joins both radio and TV stations, as is the case in Norway where, in 1997, broadcasting standards are fully maintained by a board of self ethical council ${ }^{14}$. Traditionally, ethical councils were limited to written press, given the legal and state institutions governing the audiovisual sector. However, as technological developments in the media industry erase the boundaries between print (written press), electronic and broadcast media, it becomes necessary to redefine the exclusive mandate ethical councils.

Germany - German Press Council. German Ethics Council, Deutscher Presserat ${ }^{15}$, receives complaints and seeks to promote high standards and fight for press freedom.

United Kingdom - The first attempt to control than the boulevard press was the General Council of the Press in 1953, created by media owners with minimal participation of General Syndicate of Journalists. Later, it became Board of Ethics. No matter how many problems the press had and how works the negative impact of tabloid media over ethical standards, both the current system of self-regulation in the UK, solidarity and strength guild is a powerful antidote. Later, the journalists in UK founded the National Union of Journalists (NUJ) that developed and the current code of ethics of journalists. In February 2005, when it reappeared the proposal to create a council of state regulated press, a minister presented at the debate concluded his statement in favor of keeping the current model of self-regulation of the press in this way: "The government has no intention of put an end to 300 years of press freedom $" 16$.

\section{Conclusions}

Generally, journalists accept regulations that protect vulnerable people against state action, other institution or powerful individuals, but reject those that restrict democratic debate. But in most cases, journalists are afraid of legislation that would regulate them. Many journalists think that the current restrictions are too harsh, that prevents journalists to provide public services needed to carry out free speech as they would like. However, there are situations that need to be considered as requiring legislative provisions - such as audiovisual17. In most European countries the state Radio and TV was the first public television signal transmitter. Thus, broadcasting was developed as a branch of public service. The State could lead these companies through people power, people who were not always able to maintain independence. Until the late 60's in many western European democracies government considered public radio and television as an instrument of state propaganda ${ }^{18}$.

\footnotetext{
${ }^{13} \mathrm{http} / / / \mathrm{www}$.guardian.co.uk/Columnists/Archive/0,5673,-20,00.html, $6^{\text {th }}$ of March 2012.

${ }^{14} \mathrm{R}$. Shannon, A free and responsible Press, John Murray, London, 2001, p. 12.

${ }^{15}$ www.presserat.de; http://www.presserat.info/uploads/media/Press_Code.pdf; $5^{\text {th }}$ of April 2012. http://www.publications.Parliament.uk/pa/cm200405/cmhansrd/cm050225/debtext/50225-19.htm; $6^{\text {th }}$ of March 2012.

${ }^{17}$ See Article 10 (1) of the European Convention on Human Rights: "This article shall not prevent States to request authorization from the radio, TV and cinema".

${ }^{18}$ C. J. Bertrand, Media Ethics and Accountability Systems/Media Ethics \& Accountability Systems, Transaction Publishing House, Bucharest, 2000, p. 14.
} 


\section{A. Păiuşescu}

The doctrine of the audiovisual public service - first appeared on the BBC - according to which the post is obliged to serve the entire country, both opposition and government, became a majority ${ }^{19}$. The State's right to interfere is now subject to certain restrictions, legally known as "triple test" 20 . The proposed regulation must comply with Article 10 of the European Convention $^{21}$, and must be:

- Prescribed by law (e.g. a written parliamentary status publicly accessible);

- A legitimate aim (e.g. to protect legitimate public or private interest);

- Necessary in a democratic society.

\section{Bibliography}

Nicoleta Elena Buzatu, Cristina Anca Păiuşescu, "Man's Rights” or The "Harmonious Communion Between Lay and Religion in the Universal Order", Agora International of Juridical Sciences no 2/2011, Agora University Press, Oradea, 2011;

Cristina Anca Păiuşescu, Oana Duță, Dreptul comunicării. Considerații teoretice şi legislație relevantă, "Editura Universitară" Publishing House, Bucharest, 2011;

2010;

M. Luburici, Teoria generală a dreptului, Oscar Print Publishing House, Bucharest,

R. Chiriță, European Convention on Human Rights. Comments and explanations, vol.

II, “CH Beck” Publishing House, Bucharest, 2007;

C. F. Popescu, Etica jurnalistică şi legislația presei, A.N.I. Publishing House, Bucharest, 2006;

R. Shannon, A free and responsible Press, John Murray, London, 2001;

C. J. Bertrand, Media Ethics and Accountability Systems/Media Ethics \& Accountability Systems, Transaction Publishing House, Bucharest, 2000;

V. Ionescu, Unele controverse în dreptul penal la sfârşit de mileniu in "Dreptul" Review, no 7/1999;

D. T. Popa, Dreptul comunicării, Norma Publishing House, Bucharest, 1999;

European Convention on Human Rights

National Union of Journalists Ethic Code - www.nuj.org.uk

Press Code - www.presserat.de

United Kingdom Parliament - www.publications.Parliament.uk

The Guardian - www.guardian.co.uk

\footnotetext{
${ }^{19}$ Idem.

${ }^{20}$ Ibidem, p. 21.

21 R. Chiriță, European Convention on Human Rights. Comments and explanations, vol. II, "C.H. Beck" Publishing House, Bucharest, 2007, p. 82.
} 